\title{
Re-Imagining the Nation: Storytelling and Social Media in the Obama Campaigns
}

\author{
Himanee Gupta-Carlson, SUNY Empire State College
}

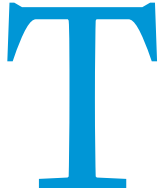

he scene is the National Mall in Washington DC. I am standing behind the reflecting pools by the Capitol Building, waiting for President Barack Obama to take the oath of office following his November 2012 re-election. I am wedged between dozens of warmly dressed people on this January morning as part of the one-million-person strong crowd. Inaugurations celebrate civic events; however, this one feels like a religious revival. As the hymn "Amazing Grace" starts to play over the audio system, the people around me sway in unison. One woman hums the first few chords. Within seconds we are all singing along. In a sense, we are experiencing an enactment of the "nation as imagined community" (Anderson 1983). Yet, as part of a crowd and set of virtual worlds that were both products of the campaign that Obama built on stories and social media, we played an active role in that imagining process, too.

We exchange stories of our roles within the Obama campaign, and we talk about being at this inauguration and in some cases the one before it as a part of our history, a history we helped create through making phone calls, walking our neighborhoods, donating money, sending e-mails, making Facebook posts, and casting our votes. As we talk, we listen to lines of post-Civil War history that are coming over a public address system and absorb the lessons that the failed task of the Reconstruction's rebuilding of a war-torn country had taught. Some of us evoke the call-andresponse style of dialogue that characterizes African American spiritual traditions by repeating the lines aloud. We also use cell phones, smart phones, iPads and other portable wireless devices to communicate with the world. Our photos and stories are being uploaded and shared as quickly as we can manage via the Internet with friends, students, colleagues, and others back home. These activities mirrored the methods that the Obama Organizing for America coalition pioneered and spoke to what it meant to participate politically.

"Focus on 1863, Civil War, runs deep," I type into a text message that my husband subsequently posts to Facebook. "Speaks to divisiveness of politics over past few years and Obama's calls to come together."

"'Our Journey is not complete'," responds a student on Facebook, citing a phrase from Obama's speech.

"Wow," the student adds, "I have chills."

\section{STORIES AND PRESIDENTIAL ELECTIONS}

The creation of stories and the rituals of storytelling are no strangers to American elections, particularly the presidential race. No presidential election has taken place since the early nineteenth century without an infusion of stories about the candidate's life and that individual's quest for the White House (Romagnuolo 2013). These stories gain narrative energy through their paralleling of stories of the nation, making the candidate-as-protagonist a metaphor for the nationin-making. This process of narrativity supports Benedict Anderson's (1983) argument that nations are not fixed, tangible entities that exist in and of themselves but rather ideas that must be imagined routinely into being through the enactment of rituals involving national symbols. Hundreds of thousands of people who are unlikely to meet face-to-face participate in these rituals and in doing so, Anderson suggests, come to imagine themselves as belonging to a "nation" whose people possess a shared set of beliefs and values $(3-4,6-8)$. While Anderson presumes a top-down approach, I suggest in this essay that practices associated with the emergent field of digital storytelling and growing uses of social media enabled the Obama campaign to transform a traditional campaign narrative into a collective story that made the metaphor for nation not only the candidate but also "all of us."

Since the late twentieth century, the stories that presidential campaigns tell of their candidates and the nation also have been digital in nature. They are built as multi-media narratives that use words as well as visual imagery, music, speeches, and other auditory effects to convey their message. They then are distributed across mass media to a vast audience of American consumers via television ads and national convention speeches (Lundby 2008). Through the use of television commercials, candidates can connect with voters by looking into cameras and creating an appearance of addressing their "fellow Americans" directly. In this way, the candidates create a self-image of themselves and the nation that remains part of their rendition of what it means to be American long after the election has ended (Moss 2011). Think, for instance, of Abraham Lincoln's "a nation divided cannot stand," Dwight D. Eisenhower's “peace with honor," John F. Kennedy's “ask not what your country can do for you but what you can do for your country," Ronald Reagan's "morning in America”, and Bill Clinton's belief "in a place called Hope."

The stories prepared for Obama's 2008 and 2012 races resemble these traditional presidential campaign narratives in several respects. Obama relied heavily on television commercials to get his message across, with his campaign spending in 2012 reaching \$404 million (Romagnuola 2013, 55). 
Obama's campaign also fused elements of his childhood and life accomplishments with images of American values and beliefs. In doing so, his story conveyed a sense that he - an African American man of mixed-race heritage - was a metaphor for the current America. He, like America, was a nation divided, a nation in need of healing, healing that could be accomplished by the American people's electing of him. From the decision to launch his 2008 campaign from the Old State Capitol in Springfield, Illinois where Lincoln had declared that a "house divided could not stand" to his declaration at
The technological modes of communication that the Obama era enjoyed did not exist in Clinton's time, of course, and the fact that the ability to respond in immediate real-time with stories of one's own can and has been used to further reactionary political agendas that run counter to the narrative that Obama sought to convey points to one risk that candidates face with the deployment of social media. Nevertheless, the means of public address that Clinton and Obama used point to two different uses of story: One is crafted to incite a singular response while the other seeks a ripple effect.

\section{... Obama built a compelling story rich with historical referent, a story that allowed him not only to establish himself as a protagonist with a major struggle to overcome but also to create a call for support that both in its narrative energy and in its campaign outreach could strike a strong enough chord to secure votes.}

his 2013 inaugural address that the rebuilding of the nation was not yet complete, Obama built a compelling story rich with historical referent, a story that allowed him not only to establish himself as a protagonist with a major struggle to overcome but also to create a call for support that both in its narrative energy and in its campaign outreach could strike a strong enough chord to secure votes.

But the Obama campaign took that traditional candidate story a step further, making it less of a one-way narrative and more of a collective tale. By integrating the traditional art of storytelling with the emergent technologies of social media, the campaign became a narrative that was not just about the person running for president but rather about all of "us." In the process, as the bodies swaying in unison to "Amazing Grace" at the 2013 inauguration suggest, the idea of the nation as imagined community was re-scripted, becoming a mode for considering nation-making less as a process imposed from above and more of a collective participatory effort below.

\section{DIGITAL STORYTELLING}

Practitioners of digital storytelling define this emergent practice as a democratizing art that challenges the one-way authority of traditional narrative. To understand how the Obama campaign capitalized on this practice, let's compare two candidates' speeches: During his 1992 presidential campaign, Bill Clinton visited Seattle - the city where I was living - a few times. He would close out his rallies by conjoining the word "hope" with the name of the town in which he grew up. I recall going to these rallies and listening intently. As I would look around, I would see others listening, too. Sixteen years later, I watched many of Obama's speeches via YouTube or television while in groups that consisted of other campaign supporters, as well as live at the inaugurations. I enjoyed feeling that energy in the crowds around me. But even as I joined in the crowd in listening to him, my sole focus was not on listening. I also was sharing what I was experiencing. I would type text messages, e-mails, and Facebook status updates. As I would look around, most others were doing the same. In a sense, Clinton was asking his followers to listen and Obama was motivating supporters to act.
Earlier, I described the traditional campaign stories of the late twentieth and early twenty-first century as "digital" because of their use of textual, visual, and audio elements as well as their distribution through mass media. Despite this deployment of mass media, the stories crafted by campaigns before 2008 were primarily one-way tales. They were designed to introduce the candidate to the populace and to exhort individuals to vote. Obama expected more: "It's not enough [for a supporter] to have a bumper sticker," was how one member of Obama's team put it. "We want you to give five dollars, make some calls, host an event" (Green 2008, 62).

Obama was not the first presidential candidate to use social media to mobilize support. Such practices had received a trial run through Howard Dean's failed 2004 bid for the Democratic nomination, an enterprise that led to the ongoing uses of social media through the MoveOn.org network (Green 2008). However, the campaign's quick grasp of the potential of social media to turn campaign stories into communal affairs made its fusing of stories with social media among the largest and most successful such ventures to date (Green 2008; Lutz 2009; Aaker and Smith 2010; Rutledge 2013).

Some of the reason for this success might be related to Obama's background as a community organizer himself. In the traditions of community organizing and the spiritual nature of call-and-response, stories lose their sole authorship when opened up to response. Candidates and their campaigns are subject to immediate and potentially hostile critique. Critique is likely to come eventually; however, the one-way mode of delivery allows for a buffer between the candidate and constituents. That buffer disappears when stories move from traditional media to the emerging Internet-based sites that are coming to be known as "new media" or "social media". In this realm, Bryan Alexander (2011) writes, "the outer frontier of stories [are] porous. Where a story begins and ends, what the container is that holds a narrative: these questions are more difficult to answer than before" (125).

The Obama campaign did not eschew the traditional narrative approach altogether. Its spending on television commercials in the 2012 campaign, for instance, was higher than that of any previous candidate except for his own 2012 
Republican rival, Mitt Romney (Romagnuola 2013), and his purchase of a full thirty minutes of air-time on seven national networks six nights before the 2008 election is said to have sealed the story that secured his victory, much as a similar tactic by Ronald Reagan did in 1980 (Allen 2008). But the campaign also embraced an idea that has long been a part of the community organizing tradition from which Obama came and is integral to the new digital storytelling practices: Stories when told from below can serve as important catalysts for experience: Joe Lambert (2012) compares digital storytellers with folk musicians, referring to the latter as populists who "sought out a way to celebrate the ordinary, the common person, and their daily battles to survive and overcome." But it was not enough to tell a singular story. Another voice had to pick up the tale, the musicians needed "to find a guitar for each person in every living room, music hall, and outdoor gathering, and teach them eight chords, a set of licks, and set them off to record to their own experience" (26-7).

\section{Stories thus offer a mode of showing how singular experiences of oppression, disempow- erment, and/or hopelessness might connect with the experiences of others who are will- ing to channel frustration with the status quo.}

social change. Stories thus offer a mode of showing how singular experiences of oppression, disempowerment, and/or hopelessness might connect with the experiences of others who are willing to channel frustration with the status quo. While it must not be forgotten that stories also have been used by Tea Party activists and other so-called white nationalist groups to counter movements for social justice, the goal of the Obama campaign and many other community activists groups is one of working for positive change. Stories, in this sense, are not meant to be fixed products but dynamic narratives that encourage interactivity and mobilize for change. As Obama himself wrote of community organizing, it is "through the songs of the church and the talk on the stoops, through the hundreds of individual stories of coming up from the South and finding any job that would pay, of raising families on threadbare budgets, of losing some children to drugs and watching others earn degrees and land jobs their parents could never aspire to," that the lessons of organizing are learned (Obama 2008, 10).

\section{DEMOCRATIZING THE STORY}

All digital stories rely on video and audio elements. Before the early twenty-first century, these qualities made digital stories quite expensive to produce, which limited the practice to those with specialized training and/or the means to purchase costly equipment. The rise of such inexpensive devices as camera-equipped cell phones in the early twenty-first century alongside the rise of social networking sites that enabled citizen storytellers to self-publish and distribute their stories through such spaces as Internet chatrooms and blogs eliminated the cost barrier. Storytellers, recognizing the potential to rearticulate their craft across a much wider base of practitioners, began organizing storytelling workshops and file-sharing sites that encouraged the creation and dissemination of stories. Many such sites as VoiceThread, Animoto, and Google's file-sharing functions have come to be used in educational settings as well as community groups to present ideas and solicit comments.

The craft of creating and sharing digital stories resonated with the feelings of ownership, intimacy, and belonging that social media has been shown to cultivate. Digital storytellers emphasize that everyone has a story to share and can engage in that sharing at a very low cost and with little specialized
Stories as a catalyst for change was a belief well understood by Obama himself. But what made the integration of stories from below such a vital component of his election was his ability to understand how social media could use the gathering and distribution of such stories to transform the understanding of his campaign from an individualized bid for the presidency into a collective effort aimed at healing the nation. The Internet-based file sharing sites that comprise social media are characterized primarily by their ability to engender dialogue. This characteristic has made such sites increasingly vital in how people communicate with friends, network professionally, and access news, information, and advice. While they lack the physical immediacy of a face-to-face contact, communications scholars and others argue that they create an unusual level of intimacy. As Pamela Rutledge (2013) writes: "Social media creates a new political dialogue. It takes the power of political messaging away from the mass media model and places it firmly into peer-to-peer, public discourse" (37).

In contrast to the passive listening that characterized viewers at the Clinton speeches, social media promotes an active engagement among users who use the technology to establish a sense of personal identity and connect with others. Kathy Herlock Jackson, Harold Dorton, and Brett Heindl (2010) cite a text message that the Obama campaign sent to supporters on the election night in 2008 just as the mainstream television networks called the race: "We just made history. All of this happened because you gave your time, talent, and passion to this campaign. All of this happened because of you. Thanks. Barack" (47). This sense of intimacy that social media engenders resonates with understandings of stories as vital components of democratic change, even as that intimacy can engender stories among reactionaries against progressive change. By creating a space where voters could connect with each other and share stories, the Obama campaign also established a space that allowed people to empower themselves to listen less to established authorities and to solve problems facing their own communities collectively on their own. By creating a way for people to believe in themselves and a willingness to share their stories, the campaign fused the traditional narrative arc of a presidential bid with a new media effort designed to build momentum from below.

The apparatus that the Obama campaign built to communicate with voters was a simple social networking site called 
MyBarackObama.com. It was designed to solicit campaign contributions, and to build a database of present and future supporters. It was easy-to-use and allowed voters to create personal profiles, build affinity groups, connect and converse with other registered voters, find or plan events, and raise money. As social media experts Jennifer Aaker and Andy Smith (2010) write, "The mission, design, and execution of the site students about the electoral process, I began to sense that some sort of new dialogue was occurring. People, as one friend described it, were talking about politics differently: They were talking about solving problems themselves instead of waiting for someone in power to do it for them.

At the inaugurations, I found myself joining the practices of storytelling with sharing via social media that the campaign

\section{By re-scripting the top-down delivery of the candidate tale so that the candidate's story became everyone's story, the Obama campaign changed the relationship between candidates and constituents.}

echoed the single goal of the grassroots effort: to provide a variety of ways for people to connect and become deeply involved" (34).

The site was launched at about the same time that Obama announced his bid for the presidency via an upload on the social media site YouTube.com. That strategy, as Monte Lutz noted, rested on a basic premise of community organizing of making "everyday people into engaged and empowered volunteers, donors, and advocates through social networks, email advocacy, text messaging, and online video" (2009). While the site's stated purpose was to raise money that the campaign in 2007 severely lacked and to create ways for supporters to connect with one another, the campaign also used the space to create incentives for supporters to share their own stories. For example, the campaign hosted a successful Dinner with Barack fund-raising event in which four donors who had given any amount and had shared stories about what motivated them to participate were selected to have dinner with Obama. These events took place twice during the campaign and were videotaped. The videos were then posted to YouTube for others to view.

The impact that the site had is seen in the numbers of Obama's social media followers. By November 2008, the campaign had connected with 5 million supporters on 15 separate social networks. Obama had 2.5 million Facebook followers; 115,00o Twitter followers; and drew some 50 million visitors to YouTube to watch Obama related videos. The site also had raised nearly $\$ 640$ million, with 8 o percent of the contributions coming in sums of $\$ 20$ or less (Aaker and Smith 2010, 36-7).

\section{FROM OBSERVATION TO INVOLVEMENT}

I cast my first presidential election ballot in 1984 in a time of much apathy and voter disillusion with the American political system. I responded to Obama's call to help heal the nation with contributions, volunteer work, and ultimately attendance at both inaugurations where, as a political science instructor, I communicated with students and others via the same social media spaces that propelled Obama to office. The catalyst for me was the idea that a $\$ 5$ donation and a willingness to start talking among friends and neighbors about creating change in our own communities might actually have an effect. As I started to see bake sales for Obama occurring in my neighborhood, hearing from more friends joining the campaign, and receiving more and more questions from my political science itself had taught. In 2009, as a community college instructor, I communicated with students via a Blackberry Curve, using text messaging, e-mail, blogging, and audio and video uploads to a social media site. Students watched the inauguration coverage, tracked my posts, and texted or e-mailed questions. Four years later, as an Empire State College faculty member, I led students who had enrolled in a Digital Storytelling course into a collaborative story about the inauguration through a social media site called Storytimed. I also used an iPhone to upload status updates and photos and video to a Facebook event page that the college promoted via its websites. More than 100 people posted comments on the Facebook page, underscoring the power of connection that social media had come to generate.

The response that my experiments generated might illustrate the real legacy of Obama's elections, which is a somber one: The nation has not healed. Even as many students in 2009 responded enthusiastically to the project of communicating with me via social media, others used the open-ness that the technologies allowed for to voice disenchantment with Obama's election and with the issues of social progressivism, racial inclusivity, and national healing that he advocated. In 2013, a friend of one of those following the Facebook event I had created bombarded the event page with sarcastic comments and incisive critiques. That individual's comments were countered by a flood of responses from the mostly proObama participants in the Facebook event. Yet, the altercation itself highlights how Obama's vision of healing has led perhaps to more disease. As a new presidential cycle approaches, anger toward Obama abounds in right-wing circles, and news reports on incidents of racially motivated violence proliferate both mainstream and social media. In the meantime, white nationalists have found a new hero seemingly in business magnate Donald Trump, whose anti-immigrant rhetoric catapulted him to the top of Republic primary polls in the summer of 2015 .

These occurrences call attention to the problematic aspects of seeking to make the campaign story less about the candidate and more about all of us. By re-scripting the topdown delivery of the candidate tale so that the candidate's story became everyone's story, the Obama campaign changed the relationship between candidates and constituents. In doing so, the campaign story became a story marked less by the quality of its narrative and more by its ability to provoke 
a response. On one hand, the intimacy of shared experiences that social media helps to create captures one piece of what Obama envisioned in his two campaigns and his years as president - a bringing together of people to share in the president's own words "stories and songs of dashed hopes and powers of endurance, of ugliness and strife, subtlety and laughter" that had helped re-create a sense of community among ourselves. On the other hand, it reiterates the fact that the work of making that community vibrant but not violent and diverse but not divisive remains a story of a presidency yet to be told.

\section{REFERENCES}

Aaker, Jennifer and Andy Smith. 2010. The Dragonfly Effect: Quick, Effective, and Powerful Ways To Use Social Media To Drive Social Change. New York: Jossey -Bass.

Alexander, Bryan. 2011. The New Digital Storytelling: Creating Narratives with New Media. New York: Praeger.

Allen, Jonathan. 2008. "The Nation as Community: Organizing Obama's Win." CQ Weekly 66 (43): 2970-74.

Anderson, Benedict. 1983, repr. 2013. Imagined Communities: Reflections on the Origin and Spread of Nationalism. London: Verso Books.
N.A. 2013. "Fifty-Seventh Presidential Inauguration, January 21, 2013," The Joint Congressional Committee on Inaugural Ceremonies. http://www. inaugural.senate.gov/about/facts-and-firsts. Retrieved April 14, 2014.

Green, Joshua. 2008. “The Amazing Money Machine: How Silicon Valley Made Barack Obama This Year's Hottest Start-up." The Atlantic 301 (25): 52-63.

Jackson, Kathy Merlock, Harold Dorton, and Brett Heindl. 2010. "A Celebration That Defined a Generation: Grant Park, New Media, and Barack Obama's Historic Victory of the US Presidency." Journal of American Culture 33 (1): 40-51.

Lambert, Joe. 2012. Digital Storytelling: Capturing Lives, Creating Community. ( $4^{\text {th }}$ edition). New York: Routledge.

Lundby, Knut. 2008. "Digital Storytelling, Mediatized Stories," in Digital Storytelling, Mediatized Stories: Self-Representations in New Media, ed. Knut Lundby, New York: Peter Lang Publishers.

Lutz, Monte. 2009. "The Social Pulpit: Barack Obama's Media Toolkit," Edelman Research, http://cyber.law.harvard.edu/sites/cyber.law.harvard. edu/files/Social\%2oPulpit\%20\%2oBarack\%20Obamas\%20Social\%20 Media\%20 Toolkit\%201.09.pdf, retrieved July 29, 2015.

Moss, Christina. 2011. "A Nation Divided: Regional Identity, National Narratives, and Senator Zell Miller in the 2004 Presidential Elections." Southern Communications Journal 76 (1): 76-96.

Obama, Barack. 2008. "Organizing Essentials.” Social Policy 38 (4): 8-10.

Romagnuolo, Anna. (2013). "The Living Image: Biographical Narratives in Presidential Campaigns." The European-English Messenger 22 (2): 54-6o.

Rutledge, Pamela. 2013. "How Obama Won the Social Media Battle in the 2012 Presidential Campaign." The National Psychologist. January/ February 2013: 12 


\section{APSA Task Force Reports}

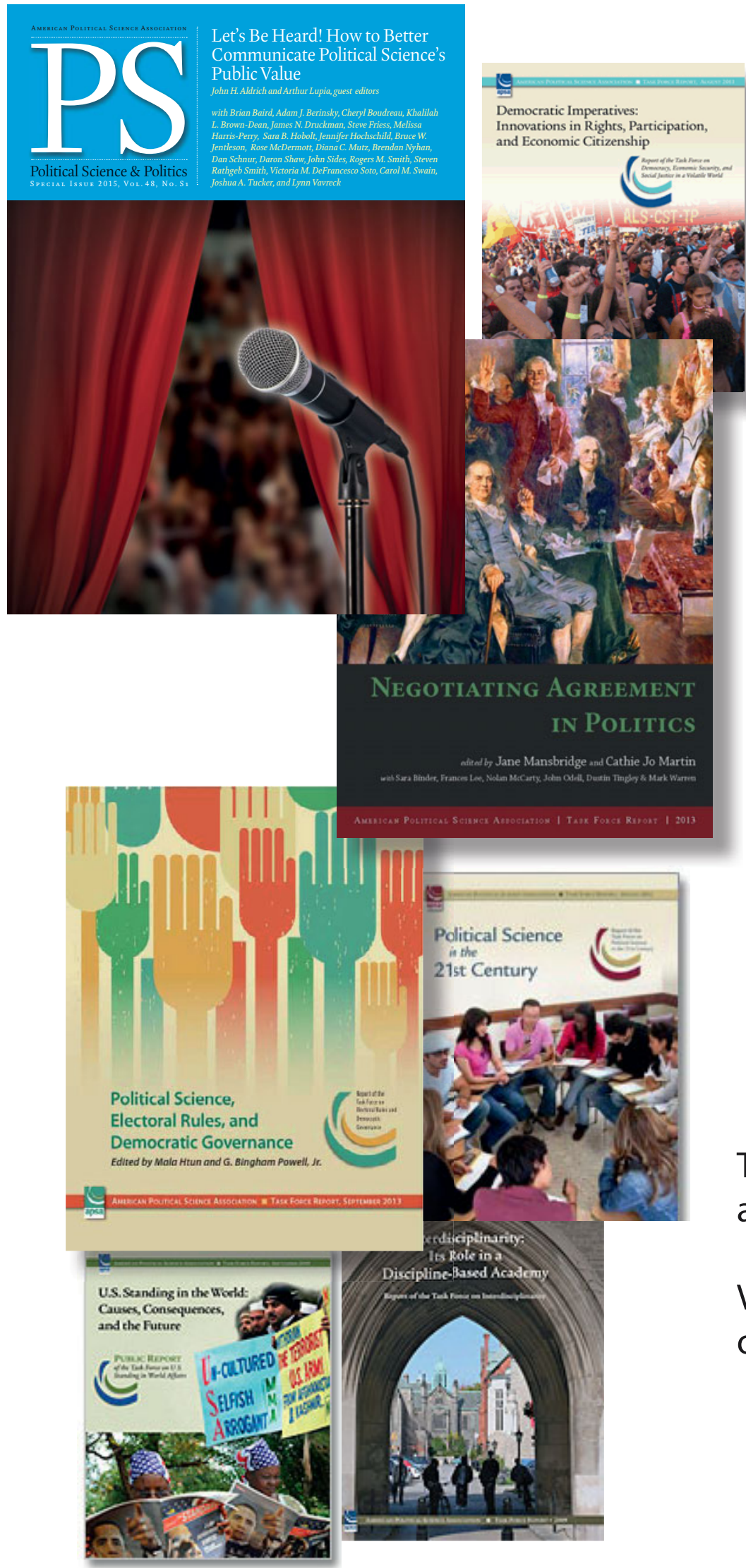

The APSA task force reports seek to expand the public presence of political science by:

- applying political science research to public policy issues,

- and sharing expertise on the most significant topics of public concern.

\section{APSA's current task force report!}

Let's Be Heard! How to Better Communicate Political Science's Public Value, in a special issue of PS

Read the complete APSA task force report, which identifies how individual scholars and professional organizations can make political science's insights and discoveries more accessible, more relevant, and more valuable to more people.

These reports and others are also available as FREE .pdf downloads!

Visit www.apsanet.org/reports to obtain your APSA task force publications.

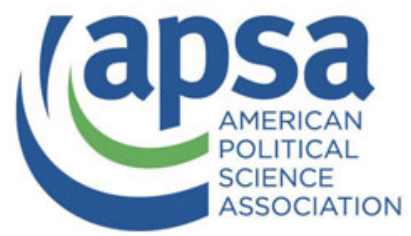

For questions or concerns, please contact publications@apsanet.org. 